\title{
DINAMIKA PERUBAHAN PENGGUNAAN LAHAN INDUSTRI KAITANNYA DENGAN PDRB SEKTOR INDUSTRI DI JABODETABEK
}

\section{An Analysis of a Change of Land Use Industry Relation to Growth Domestic Product in the Greater Jakarta Area}

\author{
Dewi Setyowati1)*, Khursatul Munibah2), dan Setia Hadi3) \\ 1) Program Studi Ilmu Perencanaan Wilayah, Sekolah Pascasarjana IPB Dramaga, Bogor 16680 \\ 2) Departemen Ilmu Tanah dan Sumberdaya Lahan, Fakultas Pertanian, Jl. Meranti Kampus IPB Dramaga, Bogor \\ 16680
}

\begin{abstract}
The development of industrial areas in Jabodetabek developed rapidly since the beginning of 1970. The rapid urban development in the Greater Jakarta resulted in the emergence of new areas on the outskirts of the city as a container for the growth of activities, such as industrial areas. This condition occurs because of the limited supply of urban land on a large scale, especially for industrial activities. The purpose of this study was to analyze changes in land use to non-industrial land to industrial land and its relation to the GDP in Jabodetabek industry and analyzes the factors that affect the industrial sector GDP. The method used in this research are the survey, GIS analysis and regression. The results showed that changes in land use (conversion) non industry to 1998 to the Year 2012 are in Bekasi largest by land use type housing, open space, and rice fields. Changes in land use non industry to positively correlate with changes in the industrial sector GDP in Jabodetabek.. Variables are a strong influence on the formation of GDP industrial sector, is a variable raw material. The development of industrial sites in Greater Jakarta tends to follow them main road network forease of accessibility.
\end{abstract}

Keywords: Distribution of industrial land, Jabodetabek, industry

\section{ABSTRAK}

Pengembangan kawasan industri di Jabodetabek berkembang pesat sejak awal 1970. Perkembangan perkotaan yang pesat di Jabodetabek mengakibatkan munculnya daerah-daerah baru di pinggiran sebagai penampung pertumbuhan kegiatan kota tersebut, diantaranya adalah daerah industri. Kondisi ini terjadi karena adanya keterbatasan penyediaan lahan di perkotaan dalam skala besar terutama untuk kegiatan industri. Tujuan penelitian ini adalah menganalisis perubahan penggunaan lahan dari lahan non industri ke lahan industri dan kaitannya dengan PDRB industri di Jabodetabek serta menganalisis faktor-faktor yang berpengaruh terhadap PDRB sektor industri. Metode yang digunakan pada penelitian ini adalah metode survey, analisis SIG dan regresi. Hasil penelitian memperlihatkan bahwa perubahan penggunaan lahan (konversi) non industri ke industri tahun 1998 sampai tahun 2012 terbesar terdapat di Kabupaten Bekasi dengan jenis penggunaan lahan permukiman, ruang terbuka, dan persawahan. Perubahan penggunaan lahan non industri ke industri berkorelasi positif dengan perubahan PDRB sektor industri di Jabodetabek. Variabel yang berpengaruh kuat terhadap pembentukan PDRB sektor industri, adalah variabel bahan baku. Pengembangan lokasi industri di Jabodetabek cenderung mengikuti jaringan jalan utama untuk kemudahan aksesibilitas.

Kata kunci: Sebaran lahan industri, Jabodetabek, industri

\section{PENDAHULUAN}

Pengembangan kawasan industri di Jabodetabek berkembang pesat sejak awal tahun 1970 oleh Badan Usaha Milik Negara (BUMN) sebagai reaksi terhadap peningkatan penanaman modal di bidang perindustrian. Untuk mendorong pembangunan industri dilakukan pembangunan kawasan industri, hal tersebut diatur dalam Peraturan Pemerintah No.24 Tahun 2009 tentang kawasan industri. Seiring dengan meningkatnya perkembangan investasi, maka pada saat itu munculah kawasan-kawasan industri baru seperti beberapa tempat di Jabodetabek (Kwanda, 2000). Kawasan industri baru tersebut antara lain: kawasan industri Pulo Gadung Jakarta, kawasan industri Jababeka Bekasi, kawasan industri Sentul Bogor, kawasan industri Pasar Kemis Tangerang.

Kota Jakarta pada tahun 1980 an mengalami pertumbuhan sangat pesat, sehingga mengakibatkan sulitnya mencari lahan bagi pengembangan kegiatan maupun untuk penyediaan sarana dan prasarana. Akibatnya banyak kegiatan industri dan permukiman diarahkan pembangunannya ke daerah pinggiran atau kotakota di sekitar Jakarta, seperti Bogor, Depok, Tangerang, Bekasi. Tujuannya adalah tentunya untuk mengurangi beban Kota Jakarta. Hal ini menimbulkan zona industri yang sudah ada sejak tahun 1970, sehingga di Jabodetabek mengalami perkembangan pesat (Tjahjati, 1995). 
Peranan kawasan industri di kawasan Jabodetabek dalam perekonomian nasional untuk beberapa tahun ke depan dinilai masih akan tetap tinggi. Sektor industri pengolahan secara nasional meningkat, sesuai data PDB (Produk Domestik Bruto) Indonesia, BPS menurut presentase kontribusi sektoral dari 22.3\% (tahun 1993) menjadi $23.6 \%$ (tahun 2013) akan meningkatkan pula pertumbuhan sektor-sektor tersebut di Jabodetabek.

Tumbuhnya kegiatan industri menimbulkan munculnya kawasan industri atau zona industri. Pertumbuhan sektor industri di suatu wilayah tidak terlepas dari peran daerah belakangnya (hinterland). Namun demikian hal tersebut dapat menimbulkan adanya pergeseran fungsi kota inti (nodal), DKI Jakarta dari pusat manufaktur menjadi kegiatan jasa-jasa, termasuk keuangan (finance). Sementara itu, kegiatan manufaktur bergeser ke arah pinggiran kota (Firman, 1996). Secara fisik proses restrukturisasi ditandai dengan perubahan penggunaan lahan (land use) baik di kota inti (nodal) maupun di pinggiran. Kawasan pusat kota mengalami perubahan penggunaan lahan yang sangat intensif dari kawasan permukiman menjadi kawasan bisnis, perkantoran, perhotelan dan sebagainya. Di lain pihak, kawasan pinggiran kota terjadi alih fungsi (konversi) pengunaan lahan secara besar-besaran dari tanah pertanian subur ke kawasan industri dan permukiman berskala besar (Firman, 1996). Industrialisasi di kawasan pinggir kota tumbuh bersamaan dengan pengembangan perekonomian kota (Grotewold, 1971).

Penelitian-penelitian sebelumnya yang berlokasi di Jabodetabek tentang industri belum banyak mengkaji tentang faktor-faktor apa yang mempengaruhi PDRB sektor industri di Jabodetabek. Tujuan penelitian ini adalah (1) menganalisis perubahan penggunaan lahan non industri ke lahan industri dan kaitannya dengan PDRB industri, dan (2) menganalisis faktor-faktor internal yang berpengaruh terhadap PDRB sektor industri.

\section{BAHAN DAN METODE}

Penelitian ini dilaksanakan di wilayah Jabodetabek, kabupaten atau kota antara lain DKI Jakarta, Kabupaten Bogor, Kota Bogor, Kabupaten Bekasi, Kota Bekasi, Kabupaten Tangerang, Kota Tangerang, Kota Depok dan Kota Tangerang Selatan.

Data yang digunakan dalam penelitian ini terdiri data sekunder dan data primer. Data sekunder yang digunakan antara lain: rencana tata ruang wilayah (RTRW), data statistik wilayah, Peraturan Presiden No.54/2008 tentang Penataan Ruang Jabodetabek, penggunaan lahan RBI Jabodetabek tahun 1998 dan 2012, serta studi-studi literatur lainnya. Sedangkan data primernya adalah pengamatan lapangan, observasi, wawancara serta dokumentasi visual berupa foto atau gambar.

\section{Identifikasi Perubahan Penggunaan Lahan Industri}

Analisis ini digunakan untuk mengetahui perubahan penggunaan lahan non industri ke lahan industri di Jabodetabek dengan menggunakan peta penggunaan lahan dari Badan Pertanahan Nasional (BPN) Tahun 1998 dan 2012. Pengolahan data dengan melakukan proses overlay (tumpang tindih) antara peta penggunaan lahan dua tahun tersebut dengan menggunakan software ArcGIS 10.

\section{Analisis Faktor-Faktor yang Mempengaruhi PDRB Sektor Industri}

\section{Analisis Korelasi}

Analisis korelasi adalah metode statistik yang digunakan untuk mengetahui derajat hubungan linear antara dua variabel atau lebih yang bersifat kuantitatif. Adanya perubahan sebuah variabel disebabkan oleh perubahan variabel lain, koefisien perubahannya dinyatakan dalam koefisien korelasi. Semakin besar koefisien korelasi maka akan semakin besar keterkaitan perubahan suatu variabel dengan variabel yang lain (Sudjana, 1989). Nilai korelasi berkisar antara -1 dan 1 . Apabila $r=-1$ artinya korelasi negatif sempurna, $r=0$ artinya tidak ada korelasi dan $r=1$ artinya korelasinya sangat kuat. Analisis korelasi digunakan untuk mengetahui keterkaitan antara perubahan penggunaan lahan non industri ke lahan industri dengan perubahan PDRB industri. Hal ini dinyatakan dalam rumus: (Sudjana, 1989).

$$
\begin{aligned}
& \mathrm{r}^{2}=\frac{\left.\sum \overline{\mathrm{Y}}_{\mathrm{i}}-\mathrm{Y}\right)^{2}-\sum\left(\mathrm{Y}_{\mathrm{i}}-\hat{\mathrm{Y}}_{\mathrm{i}}\right)^{2}}{\sum\left(\overline{\mathrm{Y}}_{\mathrm{i}}-\mathrm{Y}\right)^{2}} \\
& r_{x y}=\frac{n \sum X_{i} Y_{i}-\left(\sum X_{i}\right)\left(\sum Y_{i}\right)}{\sqrt{\left\{n \sum X_{i}^{2}-\left(\sum X_{i}\right)^{2}\right\}} \sqrt{\left\{n \sum Y_{i}^{2}-\left(\sum Y_{i}\right)^{2}\right\}}}
\end{aligned}
$$$$
\begin{array}{ll}
\mathrm{r}^{2} & =\text { koefisien determinasi } \\
\mathrm{r} & =\text { koefisien korelasi } \\
\mathrm{Y}_{\mathrm{i}} & =\text { variabel tak bebas } \\
\hat{\mathrm{Y}}_{\mathrm{i}} & =\text { persamaan regresi } \mathrm{Y} \text { atas } \mathrm{X} \\
\mathrm{Y}_{\mathrm{N}} & =\text { rata-rata variabel } \mathrm{Y} \\
\mathrm{X}_{\mathrm{i}} & =\text { variabel bebas } \\
\mathrm{n} & =\text { jumlah data }
\end{array}
$$

\section{Analisis Biplot}

Analisis biplot merupakan suatu upaya deskriptif melalui pereduksian segugus data dalam tampilan dua atau tiga dimensi. Melalui analisis biplot akan diperoleh visualisasi dari variabel dalam bentuk grafik bidang datar. Melalui tampilan dua dimensi ini dapat divisualisasikan hubungan antar variabel. Pengolahan data analisis biplot ini dilakukan dengan software Minitab. Kolinearity antar variabel digambarkan oleh seberapa besar sudut yang terbentuk antar variabel, semakin besar sudut antar variabel semakin tidak terdapat korelasi. Analisis ini digunakan untuk mengetahui variabel-variabel faktor yang mempengaruhi PDRB Sektor industri.

\section{Analisis Regresi}

Analisis regresi merupakan sebuah teknik statistik yang digunakan untuk menggambarkan hubungan antar variabel yang diekspresikan dalam bentuk persamaan. Analisis regresi yang digunakan adalah regresi berganda yang memberikan penjelasan tentang hubungan antara variabel independen dan variabel dependen. Pengolahan 
data kemudian dilakukan dengan software Minitab dengan analisis regresi. Variabel analisis regresi tersebut yaitu:

$\mathrm{Y}=$ Variabel dependen, dalam penelitian ini PDRB (juta rupiah)

$\mathrm{C}=$ Constant

$\mathrm{X} 1=$ Variabel bahan baku (rupiah)

$\mathrm{X} 2$ = Variabel jumlah tenaga kerja sektor industri (orang)

$\mathrm{X} 3$ = Variabel laju pertumbuhan PDRB sektor industri (\%)

$\mathrm{X} 4=$ Variabel panjang jalan $(\mathrm{m})$

$\mathrm{X} 5$ = Variabel penjualan/ pengurangan kendaraan (rupiah)

\section{HASIL DAN PEMBAHASAN}

\section{Analisis Perubahan Penggunaan Lahan Industri Tahun 1998-2012}

Sebaran lahan industri tahun 1998 dan 2012 disajikan pada Gambar 3 dan 4. Analisis perubahan penggunaan lahan dari industri ke non industri pada tahun 1998 hingga tahun 2012 dapat dilihat pada Tabel 1. Secara umum, perubahan penggunaan lahan dari non industri ke industri terbesar terdapat di Kabupaten Bekasi yaitu dari seluas 4,251.89 ha pada tahun 1998 menjadi 5,808.28 ha pada tahun 2012. Hal ini merupakan indikasi berlakunya Peraturan Daerah Kabupaten Bekasi No 13 Tahun 1998 yang menetapkan Kabupaten Bekasi sebagai zona industri. Demikian pula, perubahan penggunaan lahan untuk Kota Tangerang, pada tahun 2012 terjadi kenaikan yang pesat dari luas lahan industri yaitu sebesar $6.66 \%$ (880.04 ha) pada tahun 1998 menjadi $15.47 \%$ (3,980.45 ha). Luas lahan industri di Kabupaten Tangerang pada tahun 1998 seluas $11.88 \%(1,570.49$ ha) menjadi $18.68 \%(4,808.39$ ha) pada tahun 2012. Kondisi ini terjadi karena Kabupaten Bekasi, Kabupaten Tangerang dan Kota Tangerang merupakan kawasan yang berbatasan langsung dialokasikan sebagai kawasan industri. Selain itu, disebabkan karena harga lahan yang relatif murah untuk pengembangan industri, serta keterbatasan Kota Jakarta untuk perluasan industri.
Wilayah DKI Jakarta, merupakan lokasi strategis bagi tumbuhnya sektor industri selain sebagai ibukota negara juga memiliki kemudahan aksesibilitas sarana dan prasarana menuju pusat koleksi dan distribusi. Hal ini menyebabkan terjadinya pertambahan luas lahan industri di 5 (lima) wilayah Kota DKI Jakarta. Pertambahan luas lahan industri yang cukup besar terjadi di Jakarta Pusat, yaitu seluas 18.01 ha pada tahun 1998 menjadi 688.98 ha pada tahun 2012. Demikian pula Jakarta Barat juga terjadi pertambahan luas lahan industri yang pesat, yaitu seluas 593.25 ha pada tahun 1998 menjadi $1,307.30$ ha pada tahun 2012. Namun demikian di DKI Jakarta ada juga yang mengalami pertambahan luas lahan non industri yaitu Kota Jakarta Selatan. Di Kota Jakarta Selatan pertambahan luas lahan non industrinya mengalami kenaikan, dari 14,002.55 ha pada tahun 1998 menjadi $132,027.45$ ha pada tahun 2012 .

Gambar 1 memperlihatkan bahwa presentase luas lahan non industri terbanyak terdapat di Kabupaten Bogor pada tahun 1998 dan 2012. Hal ini karena Kabupaten Bogor memiliki keterkaitan antar wilayah di Jabodetabek membuat adanya hubungan sehingga setiap kabupaten/kota yang terkait terus berkembang. Ditambah lagi aliran investasi asing dan dalam negeri membuat banyaknya lahan non industri terus berkembang, misalnya perumahan, perdagangan dan jasa. Namun di Kabupaten Bogor masih juga banyak terdapat lahan non industri lain seperti persawahan, perkebunan dan tanah terbuka, sebesar 297,945 ha.

Gambar 2 memperlihatkan bahwa luas lahan industri di Kabupaten Bekasi paling luas di antara kabupaten/ kota lainnya di Jabodetabek. Hal ini merupakan indikasi berlakunya Perda Kabupaten Bekasi No 13 Tahun 1998 yang menetapkan Kabupaten Bekasi sebagai zona industri. Selain itu juga trend lokasi industri pada abad ini menempati daerah pinggiran yang berbatasan dengan kotakota besar. Kecenderungan ini terjadi sejak tahun 1899 dimana industri di kota-kota utama daerah terus menurun dan industri di daerah pinggiran terus meningkat (Kitagawa dan Bogue, 1955 dalam Lonsdale dan Browning, 1971).

Tabel 1. Perubahan penggunaan lahan non industri dan industri tahun 1998-2012 di Jabodetabek

\begin{tabular}{|c|c|c|c|c|c|c|c|c|c|}
\hline \multirow{3}{*}{$\mathrm{NO}$} & \multirow{3}{*}{$\begin{array}{l}\text { KOTA / } \\
\text { KABUPATEN }\end{array}$} & \multicolumn{4}{|c|}{1998} & \multicolumn{4}{|c|}{2012} \\
\hline & & \multirow{2}{*}{$\begin{array}{c}\text { Non Industri } \\
\text { (ha) }\end{array}$} & \multirow{2}{*}{$\%$} & \multirow{2}{*}{$\begin{array}{c}\text { Industri } \\
\text { (ha) }\end{array}$} & \multirow{2}{*}{$\%$} & \multirow{2}{*}{$\frac{\text { Non Industri }}{\text { (ha) }}$} & \multirow{2}{*}{$\%$} & \multirow{2}{*}{$\begin{array}{c}\text { Industri } \\
\text { (ha) }\end{array}$} & \multirow{2}{*}{$\%$} \\
\hline & & & & & & & & & \\
\hline 1 & Jakarta Selatan & 14,002 & 2.12 & 105 & 0.80 & 132,027 & 1.97 & 375.70 & 1.46 \\
\hline 2 & Jakarta Timur & 16,687 & 2.52 & 1,011 & 7.65 & 16,069 & 2.39 & 1,630 & 6.33 \\
\hline 3 & Jakarta Pusat & 4,330 & 0.65 & 18 & 0.14 & 3,659 & 0.47 & 688 & 2.68 \\
\hline 4 & Jakarta Barat & 11,331 & 1.71 & 593 & 4.49 & 10,617 & 1.61 & 1,307 & 5.08 \\
\hline 5 & Jakarta Utara & 11,318 & 1.71 & 1,390 & 10.52 & 9,892 & 1.52 & 2,816 & 10.94 \\
\hline 6 & Kabupaten Bogor & 298,944 & 45.18 & 1,693 & 12.82 & 297,945 & 45.82 & 2,691 & 10.46 \\
\hline 7 & Kota Bogor & 10,341 & 1.56 & 495 & 3.75 & 10,583 & 1.65 & 252 & 0.98 \\
\hline 8 & Kabupaten Bekasi & 133,583 & 20.19 & 4,251 & 32.18 & 132,027 & 20.26 & 5,808 & 22.57 \\
\hline 9 & Kota Bekasi & 8,750 & 1.32 & 852 & 6.45 & 8,825 & 1.39 & 776.89 & 3.02 \\
\hline 10 & $\begin{array}{l}\text { Kota Depok } \\
\text { Kabupaten }\end{array}$ & 18,653 & 2.82 & 244 & 1.85 & 18,549 & 2.86 & 348.44 & 1.35 \\
\hline 11 & Tangerang & 96,817 & 14.63 & 1,570 & 11.88 & 93,579 & 14.76 & 4,808 & 18.68 \\
\hline 12 & $\begin{array}{l}\text { Kota Tangerang } \\
\text { Kota Tangerang }\end{array}$ & 17,892 & 2.70 & 880 & 6.66 & 14,792 & 2.41 & 3,980 & 15.47 \\
\hline 13 & Selatan & 19,087 & 2.88 & 107 & 0.81 & 18,944 & 2.90 & 250 & 0.97 \\
\hline & Total & 661,741 & 100.00 & 13,214 & 100.00 & 767,513 & 100.00 & 25,736 & 100.00 \\
\hline
\end{tabular}




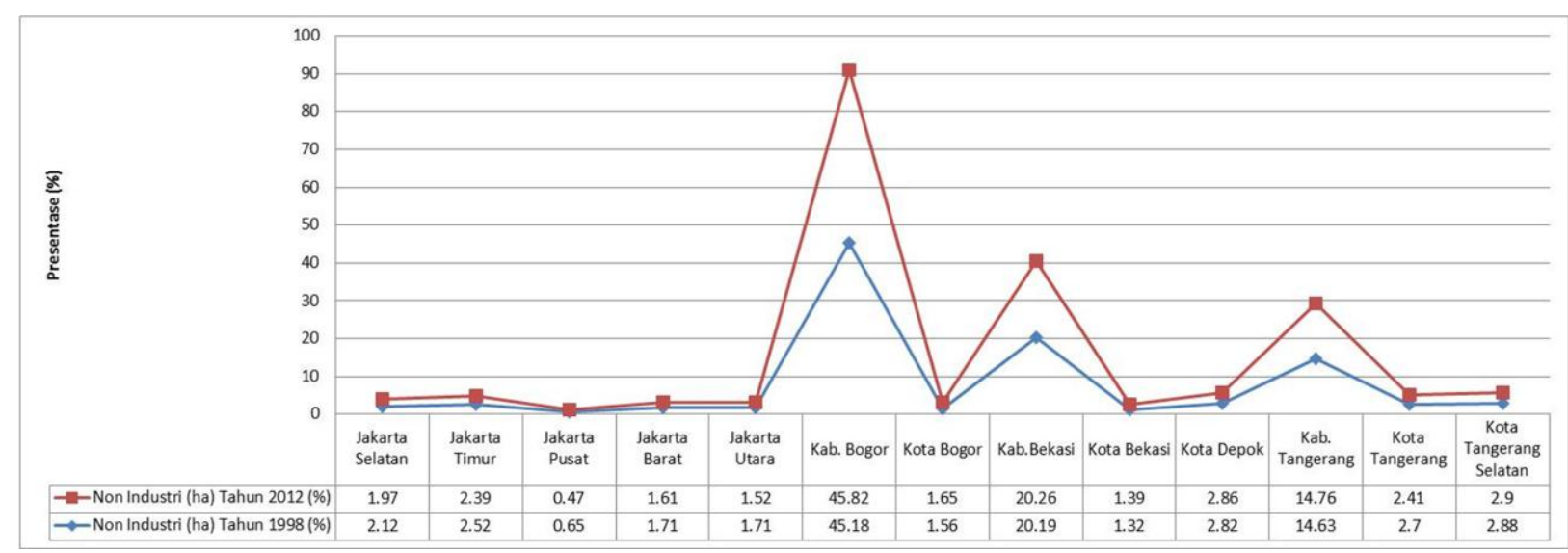

Gambar 1. Perbandingan presentase luas lahan non industri tahun 1998 dan 2012

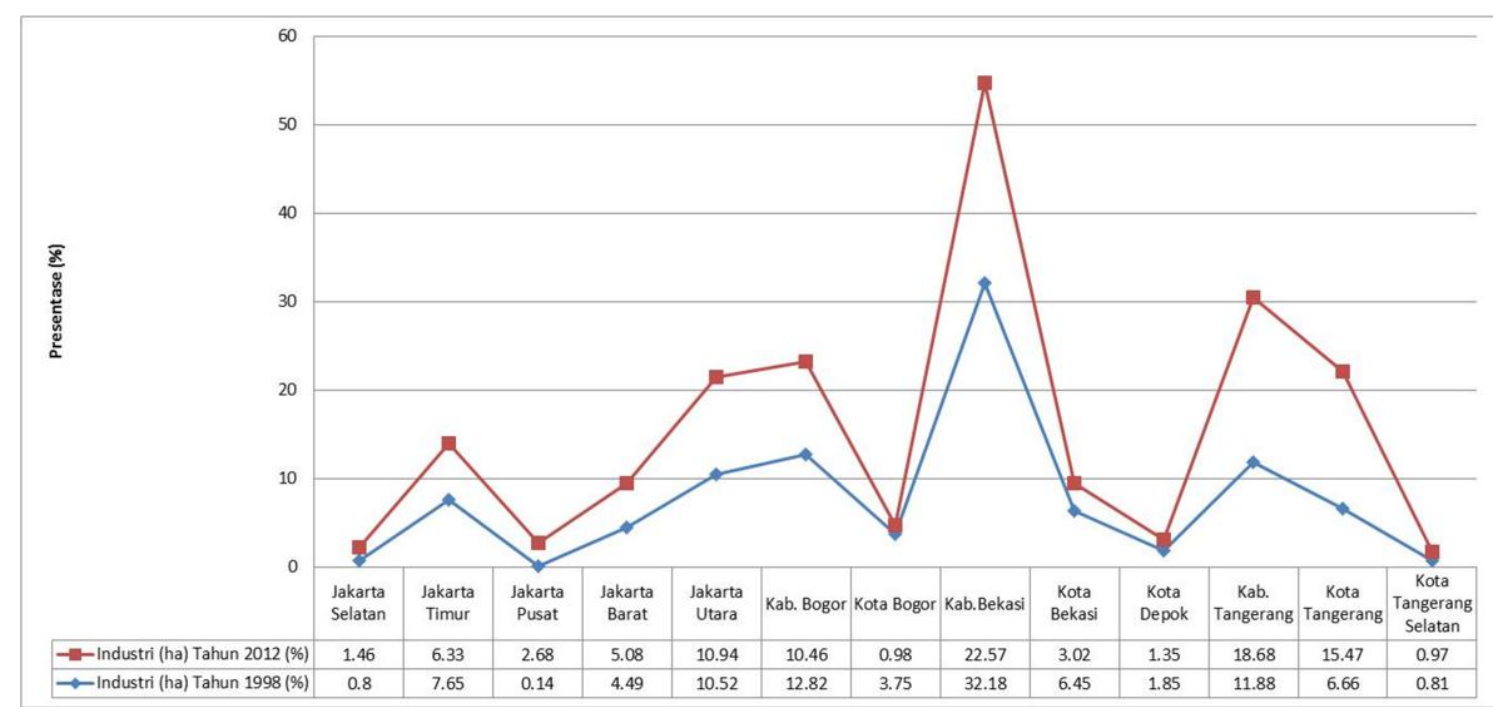

Gambar 2. Perbandingan presentase luas lahan industri tahun 1998 dan tahun 2012

\section{Analisis RTRW Kabupaten/ Kota di Jabodetabek dan Perpres No. 54 Tahun 2008 tentang Penataan Ruang Kawasan Jabodetabekjur terkait sektor industri}

Hasil analisis RTRW Kabupaten/ Kota di Jabodetabek dan Perpres No.54/ 2008, ada beberapa hal yang perlu di perhatikan dalam kebijakan sektor industri di Jabodetabek, yaitu: (1) Pengembangan lahan industri harus sesuai dengan peruntukkan lahan dalam RTRW Kabupaten/ Kota, (2) Membatasi pembangunan industri baru pada lahan industri eksisting, dan (3) Dilarang membangun industri yang mencemarkan lingkungan dan banyak menggunakan air. Ketiga hal tersebut sangat penting di perhatikan dalam pengembangan sektor industri di Jabodetabek.

\section{Analisis Sebaran Lahan Industri}

Gambar 3 menunjukkan sebaran lahan industri tahun 1998 dan 2012 cenderung berada di sekitar jaringan jalan utama yang menghubungkan antar kota dan lintas provinsi. Pada tahun 1998 lahan industri di Jakarta belum menyebar secara merata dan luas lahan industri masih relatif kecil. Hal ini terjadi karena pada saat itu dukungan prasarana dasar masih belum memadai dan keterbatasan lahan. Sementara itu pada tahun 1998 sebaran lahan industri di Kabupaten Bekasi terlihat cenderung menyebar. Hal ini karena tersedianya lahan untuk pengembang industri dan dukungan dari RTRW Kabupaten Bekasi.

Lahan industri di Jakarta banyak terdapat di wilayah Jakarta Utara terutama terkonsentrasi di dekat pelabuhan, mengikuti jaringan transportasi ke arah Barat (Tangerang) dan ke arah Timur (Bekasi). Daya tarik industri berkembang cukup pesat di wilayah Timur. Hal ini karena kemudahan aksesibilitas yang menghubungkan antar kabupaten/kota di Jabodetabek.

Hasil analisis overlay antara peta sebaran lahan industri 1998 dan 2012 menunjukkan terjadinya pertambahan alih fungsi lahan non industri ke industri. Pertambahan penggunaan lahan tersebut diperuntukkan bagi penggunaan lahan industri. Hasil overlay antara lahan industri dengan penggunaan lahan dapat dilihat pada Gambar 4. Hasil overlay peta pada Gambar 4 dapat di sajikan dalam Gambar 5. Pada Gambar 5 menunjukkan bahwa pertambahan alih fungsi lahan ke industri terbesar adalah permukiman $(5,794$ ha), kemudian diikuti persawahan (4,658 ha) dan tanah terbuka (4,595 ha). Alih fungsi lahan industri dari perkebunan memiliki jumlah paling kecil yaitu seluas 18 ha. 


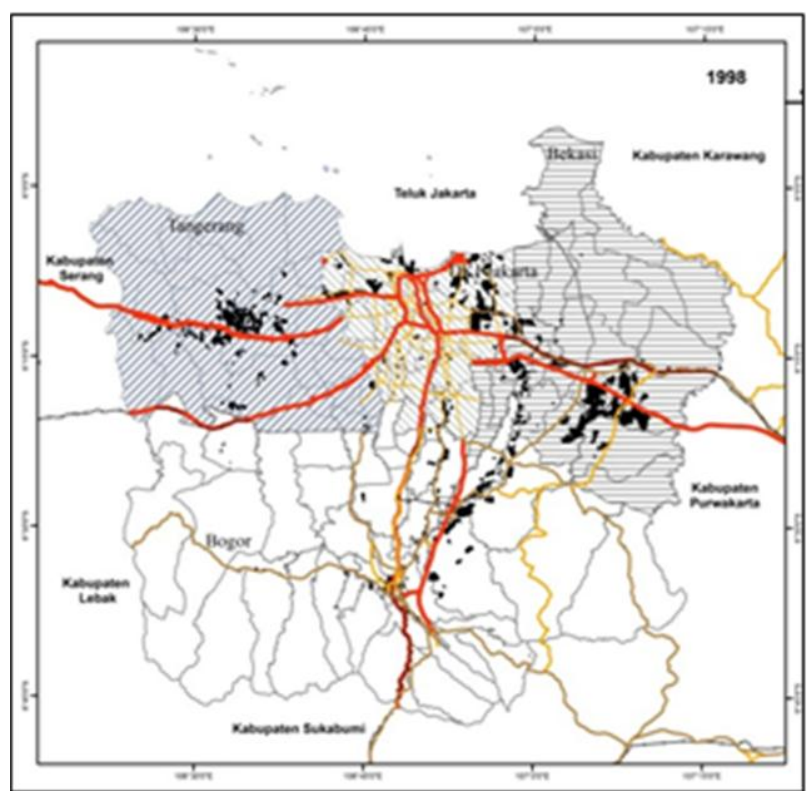

(a)

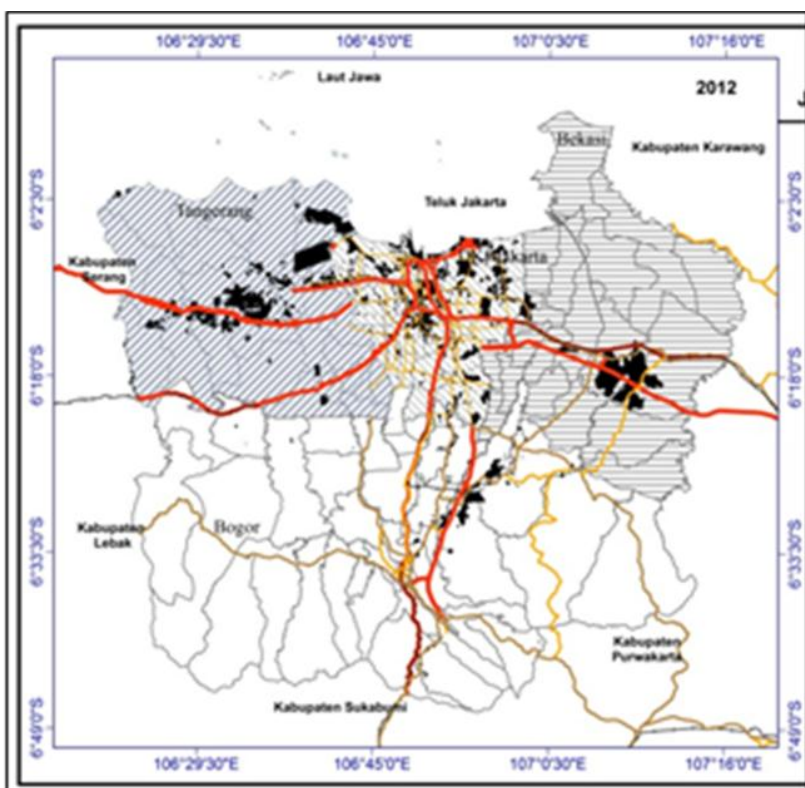

(b)

Keterangan:

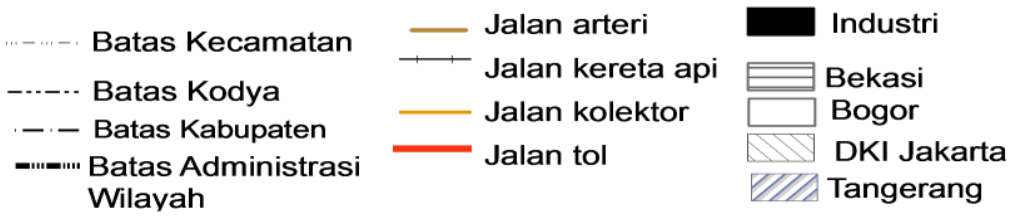

Gambar 3. Perbandingan sebaran lahan industri tahun 1998 (a) dan 2012 (b)

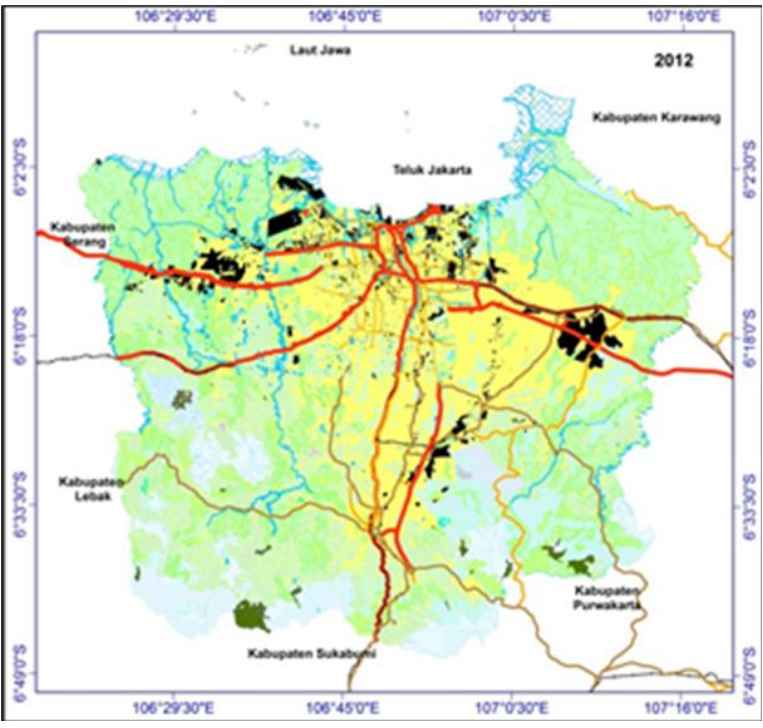

Keterangan:

\begin{tabular}{|lll}
\hline & Hutan & Permukiman \\
Kebun Campuran & & Persawahan \\
Padang & $\square$, & Sungai/Danau \\
& Perairan Darat & Tanah Terbuka \\
Pertambangan & & Tegalan/Ladang \\
Industri & Perkebunan \\
\hline
\end{tabular}

Gambar 4. Hasil overlay lahan industri dengan penggunaan lahan

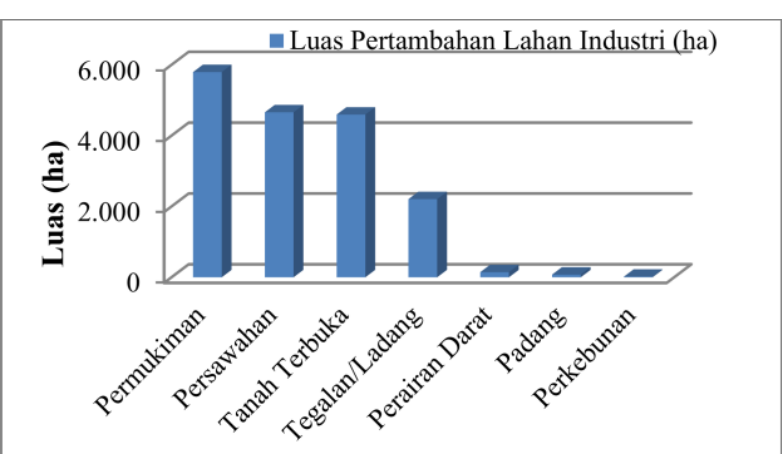

Gambar 5. Pertambahan lahan non industri ke industri di jabodetabek tahun 1998-2012

\section{Analisis Keterkaitan antara Perubahan Penggunaan Lahan Non Industri ke Industri dengan perubahan PDRB Industri}

Analisis korelasi digunakan untuk mengetahui ada tidaknya hubungan antara perubahan penggunaan lahan non industri ke industri dengan perubahan PDRB industri di Jabodetabek pada tahun 1998 hingga tahun 2012. Hasil analisis korelasi didapat nilai $r=0.632$ menunjukkan terdapat korelasi yang positif antara perubahan penggunaan lahan non industri ke industri dengan perubahan PDRB industri dimana perubahan penggunaan lahan non industri ke industri akan diikuti oleh perubahan PDRB industri. 


\section{Hubungan Antara PDRB Sektor Industri dengan Variabel-Variabel Internal yang Mempengaruhi Sektor Industri}

Berdasarkan pedoman praktis penghitungan PDRB Kabupaten/Kota (BPS, 2003), variabel-variabel internal yang mempengaruhi PDRB sektor industri yang akan ditunjukkan oleh biplot adalah (V1) bahan baku, (V2) barang yang dihasilkan, (V3) luas lahan industri, (V4) jumlah tenaga kerja, (V5) pajak, (V6) laju pertumbuhan PDRB industri atas dasar harga konstan, (V7) panjang jalan, (V8) pembelian/penambahan dan pembuatan/ perbaikan barang modal tanah dan (V9) penjualan/ pengurangan kendaraan.

Kolinearity antar variabel internal digambarkan oleh seberapa besar sudut yang terbentuk antar variabel, semakin besar sudut antar variabel semakin tidak terdapat korelasi. Dari Gambar 6, variabel-variabel internal yang mempunyai sudut terkecil, yaitu variabel V1 V2, V3, V4, V5, V8, artinya adalah ke enam variabel tersebut satu sama lain mempunyai korelasi. Analisis biplot dilakukan lagi terhadap kelompok variabel V1- V2- V3, dan V4V5, V8, karena memiliki sudut terkecil, sehingga didapat variabel-variabel internal yang tidak memiliki korelasi yaitu (1) bahan baku (V1), (2) jumlah tenaga kerja (V4), (3) laju pertumbuhan PDRB industri (V6), (4) panjang jalan (V7), dan 5) penjualan/ pengurangan kendaraan (V9).

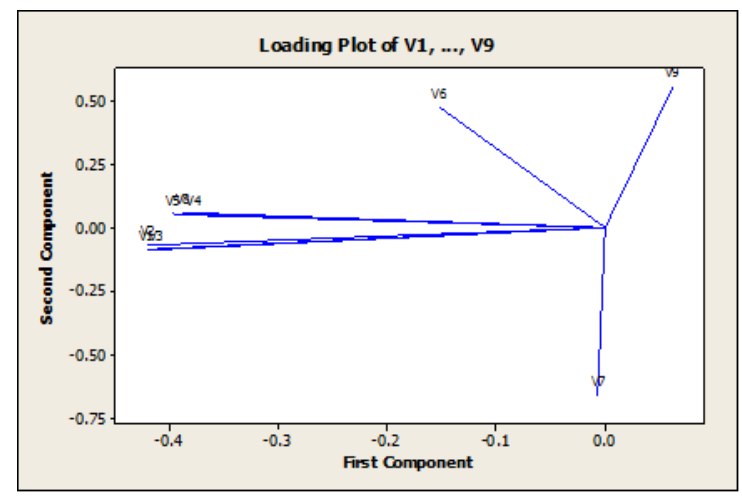

Gambar 6. Grafik biplot variabel-variable yang mempuyai sudut terkecil yang mempengaruhi PDRB sektor industri

\section{Analisis Regresi}

Analisis penentuan faktor-faktor yang mempengaruhi PDRB sektor industri dilakukan dengan menggunakan analisis regresi antara PDRB sektor industri dan variabel-variabel yang tidak memiliki korelasi di atas, sehingga menghasilkan persamaan regresi:

$\mathrm{PDRB}=-6394295+0.000395 \mathrm{~V} 1+507653 \mathrm{~V} 6+2.45$ $\mathrm{V} 7+34.8 \mathrm{~V} 4+0.00388 \mathrm{~V} 9$

Dari persamaan regresi tersebut di atas, dapat disimpulkan bahwa pada taraf kepercayaan 90\%, hanya variabel bahan baku (V1) saja yang mempunyai pengaruh terhadap PDRB sektor industri. Persamaan regresi dapat disajikan pada Gambar 7. Dari hasil analisis regresi terlihat bahwa nilai probability untuk bahan baku $<0.01$, yang artinya berpengaruh kuat terhadap pembentukkan PDRB sektor industri.
Tabel 2. Variabel internal yang mempengaruhi proses pembentukkan PDRB

\begin{tabular}{lll}
\hline No & Variabel Internal & Nilai P \\
\hline 1 & Bahan Baku & 0.069 \\
2 & Jumlah tenaga kerja & 0.339 \\
3 & Laju Pertumbuhan PDRB & 0.772 \\
4 & Panjang Jalan & 0.622 \\
5 & Penjualan/ Pengurangan Kendaraan & 0.663 \\
\hline
\end{tabular}

Keterangan: Nilai $\mathrm{P}<0.01$, artinya berpengaruh nyata

Model yang diperoleh memberikan gambaran bahwa perubahan nilai bahan baku berbanding lurus dengan PDRB industri dimana setiap penambahan 1 trilyun rupiah bahan baku akan meningkatkan PDRB sektor industri sebesar Rp. 395,000,000,-. Kenaikan PDRB sektor industri sebesar $2.50 \%$.

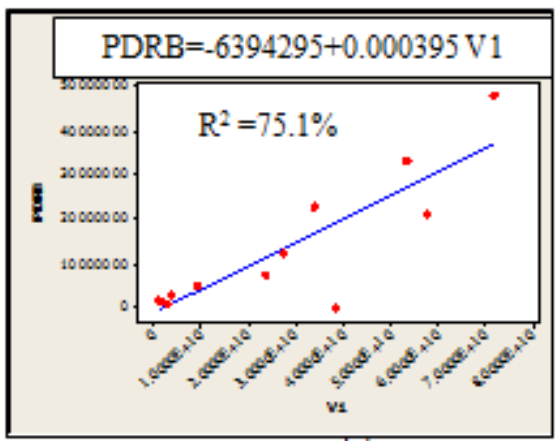

(a)

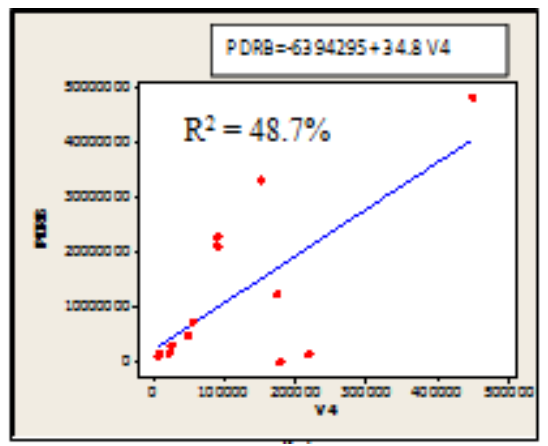

(b)

Gambar 7. Analisis regresi (a) variabel bahan baku, dan (b) tenaga kerja

Koefisien determinasi digunakan untuk melihat sejauh mana variabel bebas mampu menerangkan keragaman terikatnya. Hasil analisis regresi untuk variabel bahan baku pada Gambar 7a menunjukkan bahwa koefisien determinasi $\left(\mathrm{R}^{2}\right)$ sebesar $75.1 \%$, yang berarti variabel bebas dalam model dapat menjelaskan keragaman variabel terikat sebesar $75.1 \%$ dan sisanya diterangkan variabel bebas lainnya di luar model. Pada Gambar 7b menunjukkan hasil analisis regresi variabel internal tenaga kerja, nilai koefisien determinasinya $\left(\mathrm{R}^{2}\right)$ sebesar $48.7 \%$ berarti bahwa variabel bebas dalam model dapat menerangkan keragaman variabel terikat sebesar $48.7 \%$ dan sisanya dijelaskan variabel bebas lainnya di luar model. 


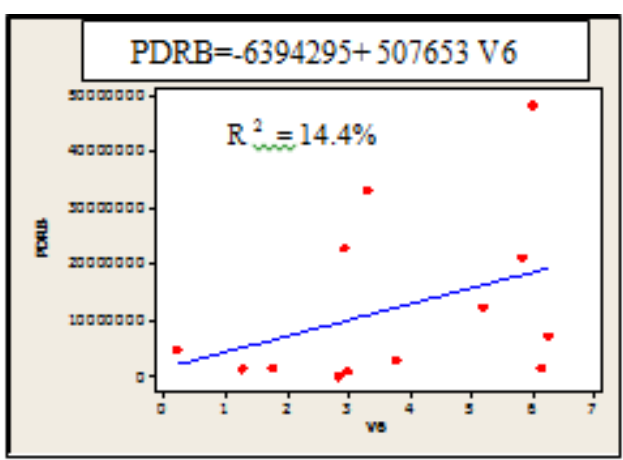

(a)

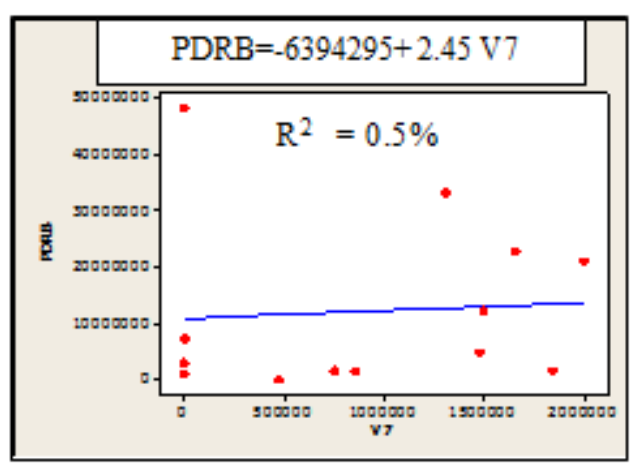

(b)

Gambar 8. Analisis regresi variabel laju, pertumbuhan PDRB (a), dan variabel panjang jalan (b)

Hasil analisis regresi variabel internal laju pertumbuhan PDRB menunjukkan nilai koefisien determinasinya $\left(\mathrm{R}^{2}\right)$ sebesar $14.4 \%$ artinya variabel bebas dalam model dapat menerangkan keragaman variabel terikat sebesar $14.4 \%$, sisanya diterangkan variabel bebas lain di luar model. Selengkapnya dapat disajikan pada Gambar 8a.

Hasil analisis regresi variabel internal panjang jalan pada Gambar 8b menunjukkan nilai koefisien determinasinya $\left(\mathrm{R}^{2}\right)$ sebesar $0.5 \%$ artinya variabel bebas dalam model dapat menerangkan keragaman variabel terikat sebesar $0.5 \%$, sisanya diterangkan variabel bebas lain di luar model.

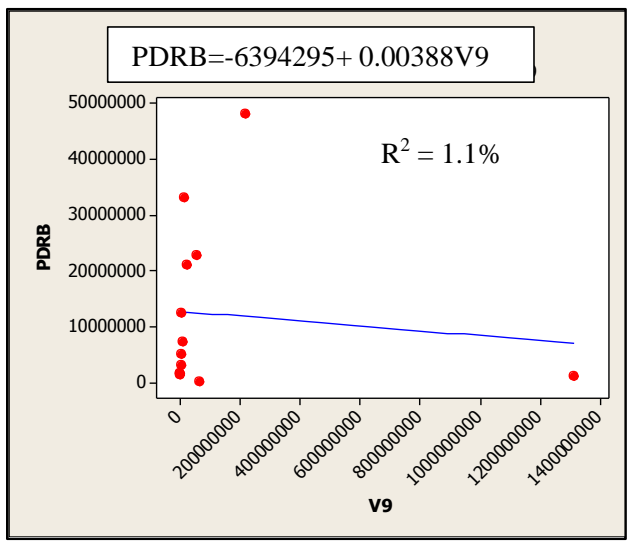

Gambar 9. Analisis regresi variabel penjualan/ pengurangan kendaraan
Hasil analisis regresi variabel penjualan/ pengurangan kendaraan pada Gambar 9 menunjukkan nilai koefisien determinasinya $\left(\mathrm{R}^{2}\right)$ sebesar $1.1 \%$, artinya variabel bebas dalam model dapat menerangkan keragaman variabel terikat sebesar $1.1 \%$, sisanya diterangkan variabel bebas lain di luar model.

\section{SIMPULAN}

Dari hasil analisis penelitian diatas, maka dapat diambil beberapa kesimpulan, yaitu:

1. Proses ekspansi perkotaan wilayah Jabodetabek dan aglomerasi industri memicu konversi lahan dari non industri ke industri. Konversi terbesar dari jenis penggunaan lahan permukiman dan tanah terbuka. Dan konversi di pinggiran Jakarta terbanyak di Kabupaten Bekasi kemudian Kabupaten Tangerang dan Kota Tangerang,

3. Terdapat hubungan yang kuat antara perubahan penggunaan lahan non industri ke industri dengan perubahan PDRB industri di Jabodetabek.

4. Dari 9 variabel yang diuji pengaruhnya terhadap pembentukkan PDRB sektor industri hanya bahan baku yang berpengaruh nyata untuk pembentukan PDRB sektor industri

\section{DAFTAR PUSTAKA}

Firman, T. 1996. Urbanisasi, persebaran penduduk dan tata ruang di Indonesia. Makalah disampaikan pada Pertemuan Pembangunan Daerah-Daerah Penyangga Pusat Pertumbuhan WIlayah Jakarta Kantor Menteri Negara Kependudukan/ BKKBN, Jakarta, Maret 1996.

Grotewold, A. 1971. The growth of industrial core areas and patterns of world trade. Jurnal Association of American Geographers, June: 361-370.

Kwanda, T. 2000. Pengembangan kawasan industri di Indonesia. Jurnal Dimensi Teknik Arsitektur., 28 (1) :54 - 61 .

Lonsdale, R.E., and C.E. Browning. 1971. Rural-urban locational preferences of Southern manufactures. Jurnal Association of American Geographers, June: 255-268.

Sudjana. 1989. Metoda Statistika. Penerbit Tarsito, Jakarta.

Tjahjati, B. 1995. Arah pengembangan kota-kota baru dalam perspektif kebijaksanaan tata ruang. Makalah disampaikan pada Seminar Strategi Pengembangan Kota-Kota Baru di Indonesia: Mengkaji Masalah dan Solusinya, Jakarta 19-20 Juni 1995. 